\title{
The Effectiveness of Foreign Exchange Market Intervention: A Review of Post-2001 Studies on Japan
}

\author{
Shinji Takagi $i^{1,2, *}$ \\ ${ }^{1}$ Graduate School of Economics, Osaka University, Osaka 560-0043, Japan \\ ${ }^{2}$ Independent Evaluation Office, International Monetary Fund, Washington DC 20431, USA
}

\begin{abstract}
Post-2001 studies on Japanese official intervention, though divergent in results, generally support the effectiveness of daily intervention in influencing yen-dollar exchange rate returns. Studies are less conclusive about the impact on volatility. Any impact of intervention appears to be short-lived and a reversal of the initial impact to occur on subsequent days, suggesting market microstructure as the primary channel: intervention acts like any other information and works through order flows. The overriding message of the literature is that the impact of intervention depends on the conditions under which it takes place. Each intervention is thus a unique event. This explains why econometric tests of the average impact of intervention yield mixed results.
\end{abstract}

Keywords: Foreign exchange market intervention, Japanese foreign exchange rate policy, great intervention, quantitative easing monetary policy.

\section{INTRODUCTION}

This paper reviews recent empirical studies on the effectiveness of foreign exchange market intervention in Japan. This literature has expanded considerably since 2001, when the Japanese Ministry of Finance (MOF) began to release daily intervention data on a quarterly basis, retroactive to April $1991 .{ }^{1}$ To the author's knowledge, no less than 40 research papers have appeared over the period 2002-13, utilizing the newly released data to analyze aspects of Japanese foreign exchange intervention. Of these, this paper reviews about 30 studies that addressed the impact of intervention on daily returns or volatility in the yendollar exchange rate for the period April 1991 - March 2004. The current review excludes the few subsequent isolated episodes of intervention that took place during 2010-11 because no study has yet emerged to analyze these sporadic events. ${ }^{2}$

Prior to 2001, empirical works on daily Japanese intervention had relied on press reports, which later turned out to be inaccurate. Frenkel, Pierdzioch, and

*Address correspondence to this author at HQ2 11-201, International Monetary Fund, $70019^{\text {th }}$ Street, NW, Washington, DC 20431 USA; Tel: 1-202-623-9909; Fax: 1-202-589-9909; E-mail: takagi@econ.osaka-u.ac.jp

JEL classification codes: F31, F41.

\footnotetext{
${ }^{1}$ In August 2000, the MOF for the first time disclosed daily intervention data on a quarterly basis, initially covering 1 April - 30 June 2000; in July 2001, it released the historical data covering the period 1 April 1991- 31 March 2000, retroactively.

${ }^{2}$ Sakata and Takeda (2013) covered the post-2004 period but focused on the impact of oral intervention (official statements) on the yen-dollar exchange rate.
}

Stadtmann (2004), comparing the Wall Street Journal and Financial Times reports with the newly released official data during January 1995 - December 1999, found that only 30 of the actual 66 interventions had been correctly reported and that there were 20 instances of false reporting. For September 1993 April 2000, Galati, Melick, and Micu (2005) observed that the probability that intervention was reported by Reuters, given that it had actually occurred, was 0.77 , while the probability that intervention had occurred, given that it was reported by Reuters, was 0.84 . For January 2000 - December 2003, Chang (2006) found that only 26 of the 101 actual interventions had been "firmly" reported, with another 45 "suspiciously" reported; there were 161 instances of false reporting. The Tokyo-based Jiji was more accurate than the Wall Street Journal when intervention had actually occurred but it had many more instances of false reporting.

The considerable literature that has now emerged demands a stock-taking exercise. Edison (1993), explaining the unsettled state of the empirical literature, appealed to (i) the lack of data on actual amounts of intervention, (ii) the fragmentation of approaches, methodologies, and sample periods across studies, and (iii) the lack of an accepted theory of exchange rate determination, as the contributing factors. Although the economics profession continues to suffer from the absence of a widely accepted theory, the recent empirical literature on Japanese intervention substantially overcomes the other two problems of the wider empirical literature. Because the studies that are reviewed here utilized the same set of data covering roughly the same period, the differences in the assessment of effectiveness could largely be 
attributable to the choice of subsample (and the associated conditions) or methodology. This is the framework we use to organize the empirical findings in this paper.

There are excellent surveys of the literature on intervention, notably Edison (1993) and Sarno and Taylor (2001); Humpage (2003) provides an overview of the state of the literature, while Truman (2003) is an insightful interpretation of the intervention experience by a former central banker. Among the more recent reviews, Neely (2005) surveys empirical studies that appeared during 1999-2004 from a methodological standpoint. Ito (2007) and Vitale (2007) both discuss unresolved issues in the literature while offering a selective survey of recent studies. The present review focuses exclusively on post-2001 studies that utilized the official Japanese data to estimate the impact of intervention on daily exchange rate returns or volatility. Though limited in country and sample coverage, this literature is rich enough to allow us to draw useful implications that go beyond the two decades of Japanese experience.

The rest of the paper is organized as follows. Section II provides a framework for reviewing the literature by giving an overview of Japanese intervention from 1991 to 2004. Section III reviews studies that estimated the impact of daily intervention on daily exchange rate returns, while Section IV reviews studies that estimated the impact of daily intervention on a measure of market volatility. Section $\mathrm{V}$ attempts to make an overall assessment of the recent literature on Japanese intervention by discussing the channels of intervention effectiveness. Finally, section VI presents a conclusion.

\section{AN OVERVIEW OF INTERVENTION, 1991-2004}

From April 1991 through March 2004, Japanese monetary authorities intervened in the foreign exchange market on 351 days. Nearly all of the interventions took place in the yen-dollar market, for the absolute amount of $¥ 68.3$ trillion, or about $\$ 612$ billion, on 345 days (Table 1). Interventions in other market segments were rare. The focus of the empirical studies reviewed in this paper has therefore appropriately been official interventions conducted in the yen-dollar market, which accounted for over 98 percent of total transactions volume. Following the intervention conducted on 16 March 2004, Japanese

Table 1: Japanese Foreign Exchange Market Intervention, April 1991 - March $2004^{1}$. (Amounts in Billions of National Currency Units)

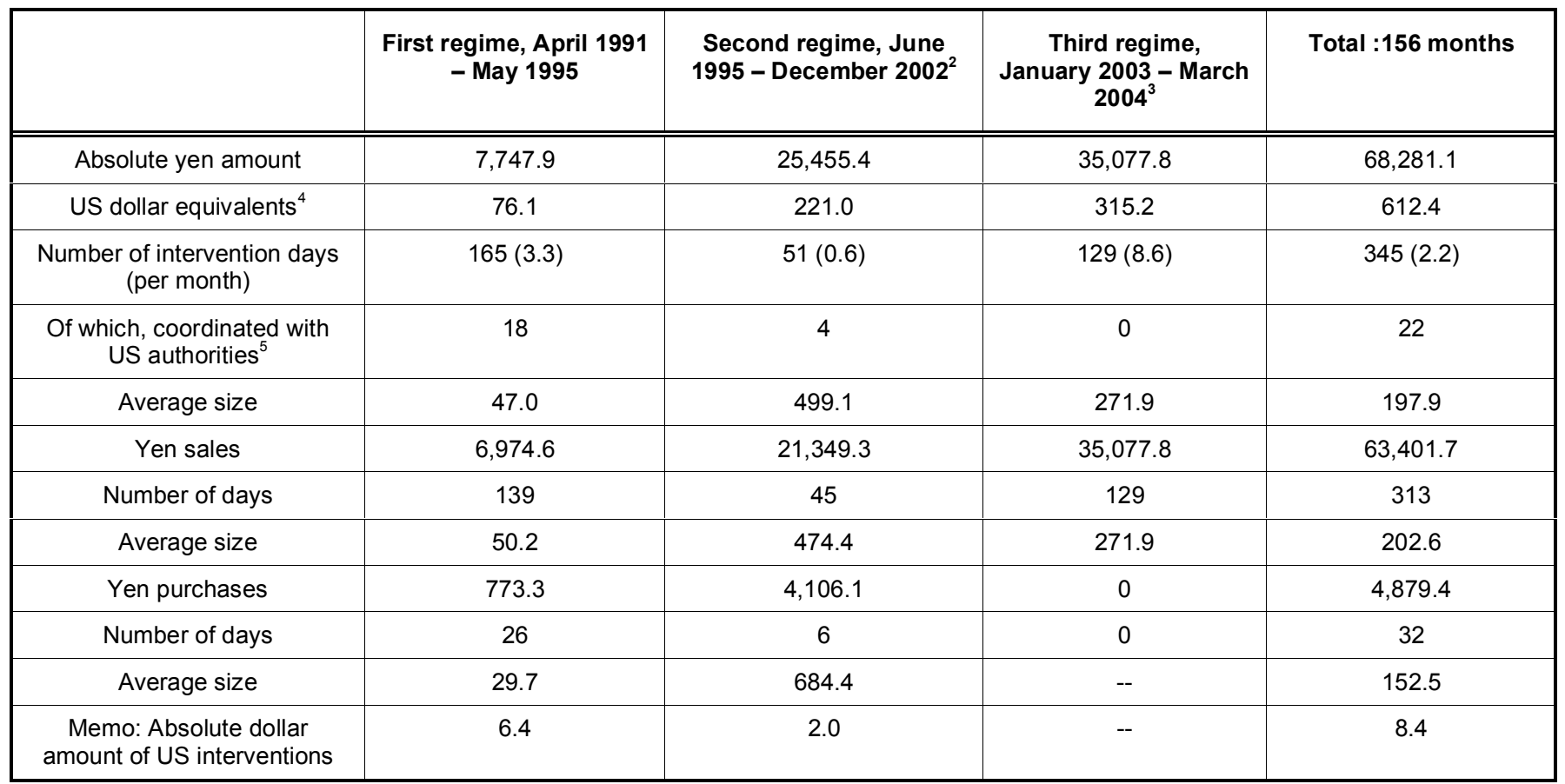

Notes: ${ }^{1}$ Includes only transactions involving yen against US dollars; ${ }^{2}$ Though Eisuke Sakakibara was appointed as Director General on 21 June, the first intervention of the month did not take place until the $28^{\text {th. }}{ }^{3}$ Though Zenbei Mizoguchi was appointed as Vice Minister on 14 January, the first intervention of the month did not take place until the $15^{\text {th }}$; ${ }^{4}$ Converted at monthly average exchange rates; ${ }^{5}$ All US interventions in the yen-dollar market during this period were coordinated with Japanese authorities.

Sources: author's estimates based on www.mof.go.jp; US Federal Reserve Board, Federal Reserve Bulletin, quarterly issues; International Monetary Fund, International Financial Statistics, monthly issues. 


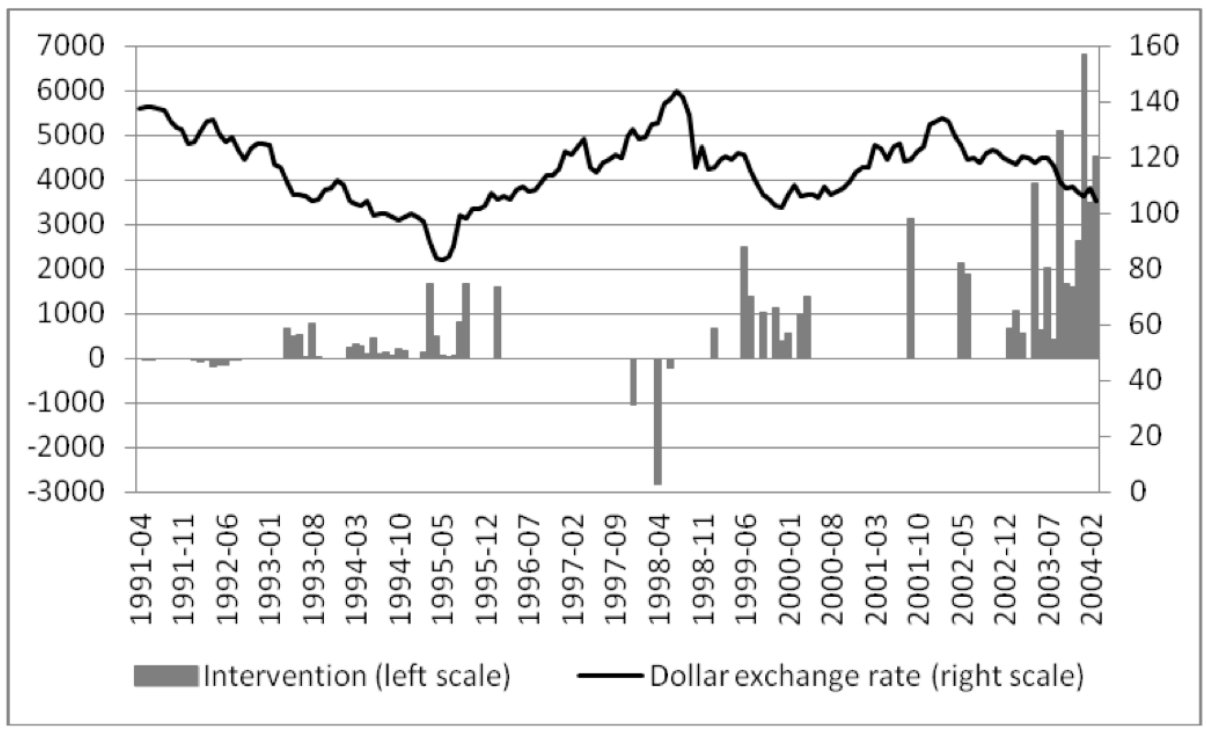

Figure 1: Intervention ${ }^{1}$ and the Yen-Dollar Exchange Rate, ${ }^{2}$ April 1991 - March 2004 (in billions of yen; yen per US dollar). Notes: ${ }^{1}$ monthly cumulative totals, with a positive (negative) number indicating a sale (purchase) of yen; ${ }^{2}$ end-of-month data. Sources: Ministry of Finance; International Monetary Fund, International Financial Statistics, monthly issues.

authorities all but ceased from intervening in the foreign exchange market. $^{3}$

Ito $(2003 ; 2007)$ proposed that the period 19912004 be usefully broken down into three regimes, the dividing points associated with the appointments of Eisuke Sakakibara as Director General of the MOF's International Finance Bureau in June 1995 and of Zenbei Mizoguchi as Vice Minister of Finance for International Affairs in January 2003. Each regime represented a different intervention tactic (Figure 1). During the first regime, interventions were conducted frequently (3.3 times a month) but in small lots ( $¥ 47$ billion per day); under the second regime, interventions were infrequent ( 0.6 times a month), but the scale was large ( $¥ 499$ billion per day); and, under the final regime, interventions were both frequent (8.6 times a month) and relatively large in scale ( $¥ 272$ billion per day).

Intervention decisions in Japan are made for the most part by a small group of MOF officials that includes the Minister of Finance, the Vice Minister for International Affairs, the Director General of the International Bureau (known as the International Finance Bureau prior to June 1998), and several other line officers. The decisions, once made, are transmitted to the trading desk at the Bank of Japan (BOJ) for execution. The BOJ has no formal role to play in decision making, so that it is inappropriate to consider

${ }^{3}$ The next intervention took place six and a half years later, on 15 September 2010, followed by isolated episodes on 18 March 2011, 4 August 2011, and five consecutive days from 31 October to 4 November 2011. official intervention in Japan as central bank intervention, as has frequently been done in the literature. Interventions are no more central bank operations than trades intermediated by a broker on behalf of clients are proprietary transactions. It is appropriate, however, to refer to the MOF and the BOJ collectively as Japanese monetary authorities.

Because the minister is typically a career politician with little professional knowledge, he often defers to the judgment of the Vice Minister in technical matters. Sakakibara $(2000$, p. 120$)$ states that, when he was appointed as Director General on 21 June 1995, he persuaded both the Minister (Masayoshi Takemura) and the Vice Minister (Takatoshi Kato) to change the tactics of intervention, from small and frequent smoothing operations to less frequent, but more decisive, ones that would carry an element of surprise and aimed to defend a particular level. The same general tactic was retained (with greater intensity) when he became Vice Minister on 15 July 1997 as well as after he was succeeded in the position by Haruhiko Kuroda on 8 July 1999. ${ }^{4}$ The tactical change was similar to the one that had occurred in other advanced countries in the 1990s, from frequent but small operations to infrequent but large ones (Galati and Melick 2002). ${ }^{4}$ The average size of intervention when Sakakibara and Kuroda successively
held the post of Vice Minister was 60 percent larger, compared to the Kato era
when Sakakibara had served as Director General. In this sense, the celebrated Sakakibara regime did not strictly begin until July 1997. 
The tactics changed again when Mizoguchi succeeded Kuroda as Vice Minister on 14 January 2003; this intervention regime is often called in the literature as the "great intervention" (Taylor 2006). Faced with yen appreciation pressure when the economy was trapped in deflation (Mizoguchi 2004), Japanese authorities sold 35 trillion yen (about $\$ 315$ billion) during the 15-month period, while the monetary base was expanded by $¥ 15$ trillion under the BOJ policy of quantitative easing. Thus, the intervention was considered to be partially unsterilized and, as such, received the support of US authorities, whose position was to "help to increase the money supply in Japan" by "adopting a more tolerant position toward intervention" (Taylor 2007, p.286).

Kim and Le (2010), by searching for news reports by Reuters, the Wall Street Journal, the Financial Times, and other sources, identified that, of the 345 days, interventions were known ("public") at the time they were conducted on 219 days while on 126 days they were not ("secret"). Beine and Bernal (2007), in explaining why some interventions remain unreported, stressed the importance of separating the inability of the market to detect interventions from monetary authorities' desire to keep them secret. Their estimation of a logit model (with secrecy=1) for 1991-2004 suggested that interventions were more likely to be detected if they were larger, coordinated, and clustered, while authorities preferred to intervene secretly when they were attempting to guide the yen away from the equilibrium value. More generally, how to engage the market must reflect the authorities' view of what strategy would work to achieve their particular goal. ${ }^{5}$

Frequently, authorities used "vocal" or "oral" interventions, i.e., official statements indicating the exchange rate's desired level or direction of change, a tool that has increasingly replaced actual interventions in other major industrial countries (Fratzscher 2005). Between January 2000 and August 2003, Park and Song (2008) identified 381 such interventions reported in the financial press (cf. 60 actual interventions), ${ }^{6}$

\footnotetext{
${ }^{5}$ For instance, interventions under Zenbei Mizoguchi were conducted almost entirely under secrecy, whereas under Takatoshi Kato, Eisuke Sakakibara and Haruhiko Kuroda authorities attempted to influence the market also through communications: according to Bloomberg and Reuters, nearly 98 percent of the interventions were reported during 1996-2002, while for 2003-4 it was only 21 percent that were detected on the same day (Beine and Bernal 2007; Beine and Lecourt 2004).

${ }^{6}$ Fratzscher (2005)'s count of vocal interventions was smaller. He counted only 137 such interventions (cf. 278 actual interventions) during 1990-2003. Vocal interventions responded much less systematically to market and monetary policy developments than did actual interventions.
}

whose frequency tended to rise when the yen appreciated against the US dollar; they also found that actual interventions typically followed several days of vocal interventions that had proven ineffective. Sakata and Takeda (2013) showed that oral intervention was effective only when those perceived to have decisionmaking authority stated their clear judgment about the prevailing exchange rate level.

Reflecting the trend appreciation of the yen over the period, Japanese authorities intervened more frequently to sell yen than to buy yen: total sales were $¥ 63.4$ trillion on 313 days, compared to total purchases of $¥ 4.9$ trillion on 32 days (see Table 1 ). No yenpurchasing intervention took place under the last regime. For the period 1990-2003, Fratzscher (2005)'s logit analysis showed that Japanese intervention was biased towards weakening the yen. Even so, there were some determined efforts to stem downward pressure on the yen when the currency, starting from a relatively depreciated level, began to edge further downward, for example, in the spring and summer of 1992 and in the aftermath of the Asian financial crisis, from late 1997 to early 1998 when Japan was also mired in an evolving banking crisis. ${ }^{7}$ The single largest intervention of this period took place on 10 April 1998, when Japanese authorities purchased 2.6 trillion yen for approximately 20 billion dollars.

From time to time, Japanese authorities coordinated intervention operations with their counterparts from other major industrial countries. Out of the 345 days on which interventions took place in the yen-dollar market, operations were coordinated on 22 days with US authorities; nearly all of them (18) took place under the first regime, while US authorities did not enter the market at all under the last regime (see Table 1). Out of the 22 days of coordinated intervention, US authorities sold yen for dollars on 18 days and purchased yen for dollars on four days. The single largest intervention by US authorities was a sale of 833 million dollars on 17 June 1998, when Japanese authorities also intervened to sell approximately 1.6 billion dollars.

\section{IMPACT ON DAILY EXCHANGE RATE RETURNS}

Japanese authorities have generally intervened to sell (purchase) yen when it was under appreciation (depreciation) pressure (see Figure 1). Thus, whether

\footnotetext{
${ }^{7}$ Two large financial institutions failed in November 1997 and another was in difficulty in 1998.
} 
or not yen sales (purchases) had the intended effect of depreciating (appreciating) the yen-or at least moderating the pace of appreciation (depreciation)has rightly been the focus of empirical investigation. This section reviews 24 studies that estimated the effectiveness of official foreign exchange market intervention in influencing the level of the daily yendollar exchange rate (or daily exchange rate returns). There are other studies that addressed the same issue, such as Beine, Laurent, and Lecourt (2003) who used weekly exchange rate returns and Dominguez (2003b) who relied on descriptive statistics. These are not formally reviewed, though references to them will be made where relevant.

Broadly, recent studies employed three methodological approaches. First, the majority of them (14 studies) used a generalized autoregressive conditional heteroskedasticity (GARCH) model or its variant to estimate the impact of intervention on daily exchange rate returns, jointly with the impact of the absolute value of intervention on conditional variance (Table 2). ${ }^{8}$ Second, four studies used a single equation; three of them used, as an instrumental variable, the predicted value obtained from an intervention reaction function. Third, six studies used non-parametric methods, including event study and propensity score matching techniques. As expected, reflecting the variety of methodologies employed, the literature reports a wide range of results, which also depend on the subsample and the particular characteristic of the intervention, for example: whether it was coordinated or unilateral; public or secret; a sale or a purchase.

A closer examination of the literature leads to a few broad generalizations (Table 2 organizes the major reported results by methodology and sample period, with the upper [lower] half summarizing the results showing effectiveness [ineffectiveness]). First, the estimates from the second, third, or combined second/third regime as well as from the entire sample period tend to support effectiveness, while those from the first or combined first/second regime tend to support effectiveness only when intervention was coordinated. Second, when distinction was made between interventions contemporaneously detected ("public") and those not detected ("secret"), the former

\footnotetext{
${ }^{8}$ Although Castren (2004) used a GARCH framework, he did not use the conditional variance equation to estimate the impact of intervention on exchange rate volatility. To measure volatility, he instead used the second moment of the risk-neutral density of expectations drawn from option prices.
}

type was more likely to be found effective. Third, when distinction was made between yen sales and purchases, it was the former type that was more likely to be found effective.

The most challenging methodological issue involves the possible feedback between intervention and the exchange rate. Simultaneity could operate at two levels. First, authorities may be prompted to intervene more decisively when the exchange rate moves more in an adverse direction. Without knowing the counterfactual (i.e., the level that would have prevailed without the intervention), an observed correlation of yen depreciation (appreciation) with yen purchases (sales) would bias the result against accepting the hypothesis of effectiveness. Second, authorities may continue intervening until they see a favorable turnaround in the exchange rate. Because the exchange rate moves with or without the intervention, an observed correlation of yen depreciation (appreciation) with yen sales (purchases) could bias the result in favor of accepting the hypothesis. The second problem is particularly relevant for event studies that treat a cluster of successive interventions as a single event (Neely 2005).

Several approaches were used to address the simultaneity problem. First, the simplest way was to use one day-lagged intervention as an explanatory variable, assuming that the impact lasts longer than a day. This was the approach taken by Beine (2004), who, by using dummy variables for lagged US and Japanese interventions, found that neither coordinated nor unilateral intervention had statistically significant impact on daily exchange rate returns for April 1991 October 2001. ${ }^{9}$ This may mean that a substantial portion of any impact of intervention was consummated within the day of the intervention, an interpretation consistent with market efficiency. The possibility that any impact of intervention was short-lived was corroborated by a study of the impact of intervention on the weekly exchange rate. Beine et al. (2003) found that lagged intervention frequency (defined as the number of intervention days during the immediately preceding week) had no impact on weekly yen-dollar exchange rate returns for 1991-5.

\footnotetext{
${ }^{9}$ The main aim of the study was to identify the impact of intervention on the covariance of the yen-dollar and the deutsche mark (euro)-dollar exchange rates. It found that coordinated Japanese and US interventions (but not unilateral interventions) increased the covariance between the two exchange rates.
} 
Table 2: Main Empirical Results on the Impact of Japanese Intervention on Daily Yen-Dollar Exchange Rate Returns (24 Studies) ${ }^{1}$

\begin{tabular}{|c|c|c|c|}
\hline \multirow{2}{*}{$\begin{array}{l}\text { Sample } \\
\text { period }^{2}\end{array}$} & \multicolumn{3}{|c|}{ Methodology } \\
\hline & GARCH-like specifications $^{3}$ & $\begin{array}{l}\text { Single equation, including use of } \\
\text { instrumental variable }\end{array}$ & Event study/non-parametric tests \\
\hline First regime & $\begin{array}{l}\text { Ito }(2003,2005,2007) \text {, Watanabe/Harada } \\
\text { (2006), Hassan (2012): coordinated } \\
\text { Kim (2007): New York } \\
\text { Kim/Le (2010): New York secret }\end{array}$ & & $\begin{array}{l}\text { Chaboud/Humpage (2005): sales in } \\
\text { moderating pace } \\
\text { Morel/Teiletche (2005): } 2 \text { and 5-day } \\
\text { windows }\end{array}$ \\
\hline $\begin{array}{l}\text { First and } \\
\text { second } \\
\text { regimes }\end{array}$ & Nagayasu (2004): coordinated & Kearns/Rigobon (2005): effect small & Fatum/Hutchison (2006) \\
\hline $\begin{array}{l}\text { Second } \\
\text { regime }\end{array}$ & $\begin{array}{l}\text { Ito }(2003,2005,2007), \text { Watanabe/Harada } \\
\text { (2006), Hillebrand/Schnable }(2006), \\
\text { Park/Song (2008), Fatum (2009) } \\
\text { Hassan (2012): sales }\end{array}$ & & $\begin{array}{l}\text { Chaboud/Humpage }(2005), \\
\text { Fatum/Hutchison }(2005,2010)\end{array}$ \\
\hline Third regime & $\begin{array}{l}\text { Ito (2003, 2005, 2007), } \\
\text { Hillebrand/Schnable (2006), Park/Song } \\
\text { (2008), Hassan (2012) } \\
\text { Fatum (2009): through end-2003 }\end{array}$ & & Morel/Teiletche (2005): 2-day window \\
\hline $\begin{array}{l}\text { Entire sample } \\
\text { period }\end{array}$ & $\begin{array}{l}\text { Kim (2007) } \\
\text { Kim/Sheen (2006): coordinated } \\
\text { Hoshikawa (2008): effectiveness } \\
\text { diminishes with frequency } \\
\text { Hassan (2012): sales }\end{array}$ & Castren (2004): Japanese (not US) & $\begin{array}{l}\text { Fratzscher (2008) } \\
\text { Chaboud/Humpage (2005): sales } \\
\text { Morel/Teiletche (2005): effectiveness } \\
\text { diminishes as window is lengthened; } \\
\text { more effective if coordinated }\end{array}$ \\
\hline $\begin{array}{l}\text { First and } \\
\text { second } \\
\text { regimes }\end{array}$ & $\begin{array}{l}\text { Nagayasu (2004): unilateral } \\
\text { Beine }(2004)^{6}\end{array}$ & & \\
\hline $\begin{array}{l}\text { Second } \\
\text { regime }\end{array}$ & Hassan (2012): purchases & $\begin{array}{l}\text { Galati/Micu (2002), } \\
\text { Galati/Meelick/Micu (2005) }\end{array}$ & Morel/Teiletche (2005) \\
\hline $\begin{array}{l}\text { Second and } \\
\text { third regimes }\end{array}$ & Kim/Le (2010): Tokyo secret & & \\
\hline Third regime & Fatum (2009): first 3 months in 2004 & & $\begin{array}{l}\text { Chaboud/Humpage }(2005), \\
\text { Fatum/Hutchison }(2005,2010)\end{array}$ \\
\hline $\begin{array}{l}\text { Entire sample } \\
\text { period }\end{array}$ & $\begin{array}{l}\text { Kim/Sheen (2006): unilateral } \\
\text { Hassan (2012): purchases }\end{array}$ & & Chaboud/Humpage (2005): purchases \\
\hline
\end{tabular}

Notes: ${ }^{1}$ Some studies are extensions of earlier studies by the same author(s): Galati, Melick, and Micu (2005) subsumed Galati and Melick (2002) for 1991-6; Ito (2005) was reproduced in Ito (2007) and subsumed Ito (2003), which covered only through March 2001; Fatum and Hutchison (2010) was reproduced in Fatum and Hutchison (2005); ${ }^{2}$ The sample period of a study may not exactly correspond to the three-regime breakdown; ${ }^{3}$ Most studies used the value of contemporaneous intervention as the key explanatory variable, jointly estimated with a conditional variance equation; ${ }^{4}$ Except for Castren (2004), use of a predicted value of intervention (jointly estimated from an intervention reaction function) to control for simultaneity; ${ }^{5}$ The dependent variable was the implied forward rate drawn from options prices; ${ }^{6} \mathrm{~A}$ dummy ( $1=$ intervention; $0=$ otherwise) was used instead of the value of intervention.

Second, some used intra-daily data by assuming that the impact lasts several hours though not necessarily longer than a day. Kim (2007) and Kim and Le (2010) divided a day into three periods 
corresponding to the Tokyo, London and New York trading hours by using the Tokyo opening, Tokyo closing, and London closing rates. Except for the small number of coordinated US interventions during New York trading, most interventions took place during Tokyo trading hours. Thus, the impact of daily intervention on subsequent returns during London or New York trading can for the most part be thought of as free from the simultaneity bias. The first study found that intervention was effective during New York hours only under the first regime, while it was effective throughout the day for the combined second/third regime as well as for the entire sample period. The second study, while confirming the same results for public interventions, found that secret interventions were effective only during New York trading (for the first regime) or London and New York trading (for the combined second/third regime). These results suggest that the simultaneity problem caused any effect of intervention to disappear during Tokyo trading, but the impact lasted long enough to be detected during London or New York trading on the same day.

Third, some studies established the counterfactual against which the intervention-induced change in the exchange rate could be measured. The counterfactual used by the non-parametric study of Chaboud and Humpage (2005) was given by the martingale property of daily exchange rate returns. Their overall assessment was that intervention was successful (in the sense that the pattern of change subsequent to intervention significantly differed from a martingale) under the second regime, for yen sales only. The counterfactual used by Fatum and Hutchison (2010) was the exchange rate return that would have prevailed in a similar condition but without intervention. In the language of the treatment literature, the authors estimated the average "treatment" effect of intervention by comparing the means between a group of observations with intervention and those with similar characteristics (in terms of a logit score from the intervention reaction equation) but without the intervention. The overall finding was that, for January 1999 - March 2004, intervention was effective only when it was infrequent, suggesting that an element of surprise was necessary for effectiveness.

Fourth, Fatum and Hutchison (2006) argue that an event study methodology is better suited to identifying the impact of intervention because the daily exchange rate is volatile and intervention comes in sporadic clusters. Using 2-day pre/post-event windows, the study found that intervention was successful in influencing the level of the exchange rate in a desired direction for April 1991 - December 2000, with greater impact for large or coordinated interventions. Morel and Teiletche (2005) came to a similar conclusion for April 1992 - October 2003 (but not for the subsample of June 1995 - February 2001), using the risk-free forward exchange rate calculated from options prices (which is nearly identical to the spot exchange rate); effectiveness diminished when the window was lengthened from 2 to 10 days. Fratzscher (2008) likewise used an event study methodology (with 5-day pre/post-event windows) to find that combined Japanese and US interventions (both actual and oral) were effective for 1990-2003.

Fifth, in order to address the simultaneity problem, Galati et al. (2005) and Kearns and Rigobon (2005) used an instrumental variable for contemporaneous intervention, namely, the predicted value from a separately estimated intervention reaction function. The first model included a set of macroeconomic news as explanatory variables to isolate the impact of intervention, whereas the complexity of addressing the feedback between intervention and the exchange rate in the friction model of Kearns and Rigobon only allowed inclusion of contemporaneous intervention. Galati et al. found no statistically significant impact of intervention on the mean of the 30-day risk-free forward rate calculated from options prices during September 1993 - April 2000. In contrast, Kearns and Rigobon found that intervention was effective for May 1991 - June 2002, though the impact was numerically very small.

All other studies used contemporaneous intervention without explicitly taking account of the simultaneity issue. Most of these studies showed that, under the first regime, intervention was ineffective or effective only when coordinated and, under the second and third regimes (or for the entire sample period) it was by and large effective. This must mean that, whatever may have been the simultaneity bias, the effectiveness of intervention was sufficiently powerful to be detected. Part of the reason may be the use of the New York closing or the Tokyo opening rate (of the following day) to calculate daily exchange rate returns. ${ }^{10}$ This was necessary to make sure that any US intervention during New York trading would be

\footnotetext{
${ }^{10}$ The only exception was Hoshikawa (2008), who used the Tokyo closing rate. This is probably inappropriate, but even this study found that intervention was effective.
} 
reflected in daily returns, but it also meant that, for Japanese interventions during Tokyo trading, calculated daily returns included a component that was sufficiently free from feedback between the exchange rate and intervention.

Though these studies shared a similar methodological framework, they asked different questions. For example, Nagayasu (2004) used dynamic analysis to suggest that any impact of intervention was short-lived, lasting only a day. Ito (2005) showed that the impact of US intervention was three times larger than Japanese intervention under the first regime, while it was 80 times larger in the second regime. On the other hand, Castren (2004), using the risk-free forward rate calculated from options prices, found that US interventions had no effect on daily returns during 1992-2003 though Japanese interventions were effective. Hoshikawa (2008) and Hassan (2012) considered the impact of frequency on effectiveness. Estimating exponential (E)-GARCH models for the entire sample period by using intervention frequency as an explanatory variable, they both found that intervention became less effective as it increased in frequency.

The differential impact of "public" versus "secret" interventions was examined by several studies. First, Galati et al. (2005), by identifying the reporting of intervention by Reuters, showed that both public and secret interventions were equally ineffective for September 1993 - April 2000. Second, Fatum and Hutchison (2006) used an event study to show that intervention was effective for April 1991 - December 2000 , regardless of whether it was reported in the Wall Street Journal. Third, Kim and Le (2010), considering intervention to be public when it was reported by Reuters, the Wall Street Journal, the Financial Times, or other archived sources in the Factiva database, found that public intervention was generally more effective. Though the findings were mixed, they appear somewhat more favorable to the relative effectiveness of public interventions because when they were ineffective secret interventions were also found ineffective.

Finally, two studies tested for the portfolio balance and signaling channels of intervention. Fatum (2009), estimating the impact on daily returns of the sizes of reported and unreported interventions that actually took place and a dummy variable for reported interventions that did not actually take place, found that only actual interventions were effective for 1999-2003; the coefficient of intervention announcements had no impact on daily returns. From this the author concluded that the portfolio balance channel, not the signaling channel, was in operation. In a direct test of the signaling effect, however, Park and Song (2008) differentiated between actual interventions (defined in terms of size) and vocal interventions (given as a dummy) to find that, from January 2000 to August 2003, secret interventions were effective only in weakening the yen, though actual interventions were consistently so. The authors interpreted this to mean that vocal interventions aimed at weakening the yen were more credible with the market.

\section{IMPACT ON DAILY EXCHANGE RATE VOLATILITY}

Monetary authorities are sometimes said to intervene when the foreign exchange market exhibits a large degree of volatility. The presumption is that intervention, if effective, reduces exchange rate volatility by conveying the superior information of authorities about future monetary policy or the equilibrium exchange rate. The existing empirical literature, however, tends to conclude otherwise. The perverse impact of intervention on volatility has become increasingly accepted since the seminal work of Dominguez (1998), who found that intervention generally increased exchange rate volatility (see also Dominguez 2003a; Dominguez and Panthaki 2003). Focusing on the yen-dollar exchange rate, Chang and Taylor (1998) came to a similar conclusion by using intra-daily (5 to 10 minute intervals) data from October 1992 to September 1993 and Reuters' announcements to identify the timing of intervention. This section reviews 16 studies that addressed this issue by using Japanese daily intervention data.

If we use the standard deviation of daily percentage returns as a measure of volatility, we detect no simple relationship between intervention and volatility in monthly data (Figure 2). It thus comes as no surprise that recent studies yielded mixed results on the impact of daily intervention on volatility. An additional complication is that different studies used different measures of volatility. Studies that unequivocally support the emerging conventional wisdom in the literature (Nagayasu 2004; Kim and Sheen 2006; Hoshikawa 2008) all employed a GARCH-type specification in which the impact of intervention on volatility is obtained from the conditional variance equation estimated jointly with a conditional mean equation (Table 3 ). The conditional variance, derived 


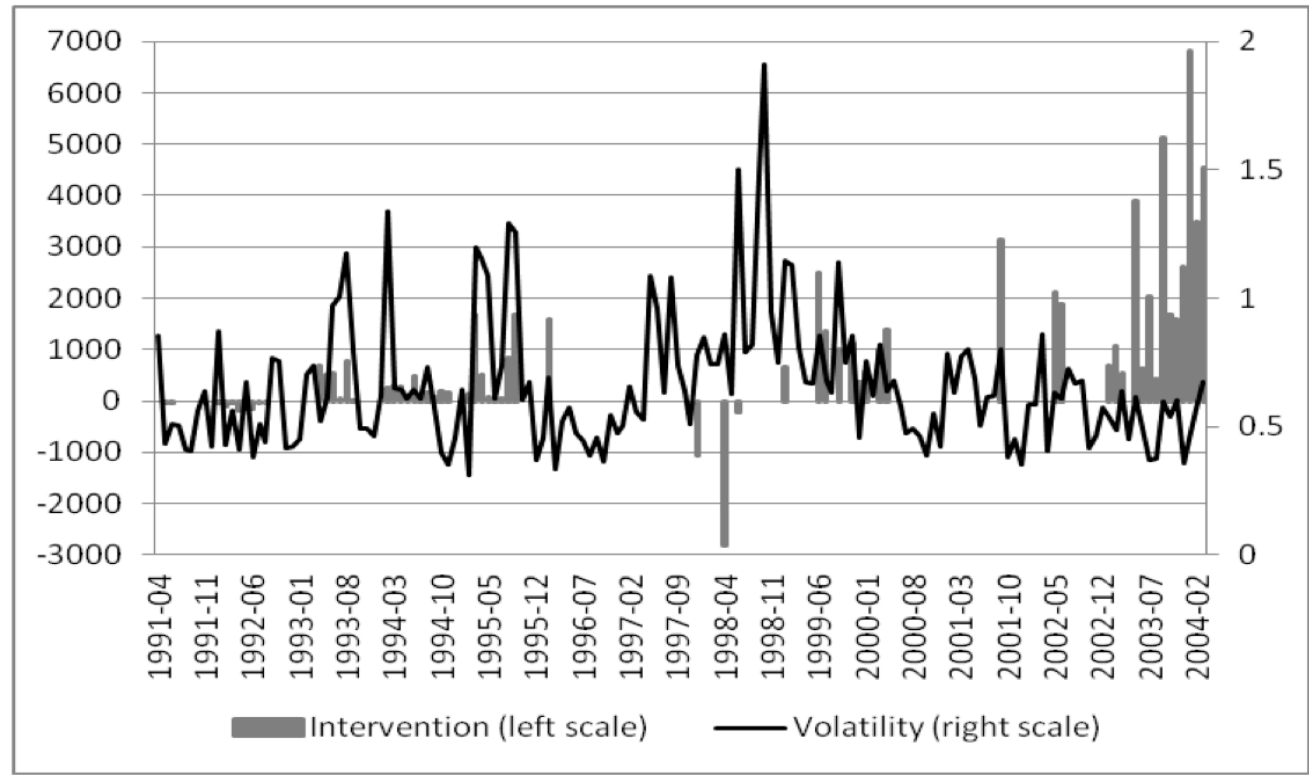

Figure 2: Intervention ${ }^{1}$ and Yen-Dollar Exchange Rate Volatility, ${ }^{2}$ April 1991 - March 2004 (in billions of yen; standard deviations of daily percentage returns).

Notes: ${ }^{1}$ monthly cumulative totals, with a positive (negative) number indicating a sale (purchase) of yen; ${ }^{2}$ monthly standard deviations of daily percentage returns, based on closing rates.

Sources: Ministry of Finance; author's estimates based on Bloomberg.

from a particular GARCH model, may not directly correspond to an observable real life measure of market volatility.

Other GARCH-type studies also support the conventional wisdom, but only conditionally, depending on the sample period or the nature of the intervention (e.g, Beine 2004; Hillebrand and Schnable 2006; Kim 2007; Kim and Le 2010; Hassan 2012). Combined, these studies seem to suggest that the impact of intervention on conditional variance tended to be positive (i) when the first regime was included in the sample, (ii) when intervention was public or coordinated, or (iii) during Tokyo trading. Although Hassan (2012) showed that the impact was negative under the first regime, the negative effect was observed only for yen sales. While Kim and Le (2010) showed that the impact was negative for secret interventions, the impact remained positive for public intervention especially during Tokyo trading. All in all, GARCH-type studies are suggestive of the possibility that official intervention, especially when recognized by the market, raised the conditional variance of daily exchange rate returns.

Some studies suggest a potential tradeoff between the two objectives of intervention-changing the conditional mean of daily returns in a desired direction and minimizing their conditional variance. Hoshikawa (2008), whose analysis covered the entire sample period, showed that intervention frequency reduced the conditional variance of daily exchange rate returns while diminishing the effectiveness of intervention in influencing their conditional mean. On this basis, the author conjectured that the purpose of intervention under the first regime (when it was frequent) was to reduce volatility, while the purpose under the second regime (when it was infrequent) was to influence the level of the exchange rate. Hassan (2012) came to a similar conclusion on the tradeoff between the two objectives, finding that successful depreciation was achieved at the expense of higher volatility. Considering the separate effects of frequency and size, the author found that frequency reduced both effectiveness and volatility while size increased both effectiveness and volatility.

Any evidence of positive impact could be an artifact of the GARCH-type methodology. Watanabe and Harada (2006) argue that, as shocks to exchange rate volatility are persistent, inclusion of intervention in the conditional variance equation presupposes persistence in the effects of intervention. In order to control for such a volatility-clustering bias, the authors assumed that volatility consists of short-term and long-term components with shorter and longer degrees of persistence, and estimated a system of three (instead of two) equations. With this correction, they obtained the result that intervention had no impact on the conditional variance of daily exchange rate returns 
Table 3: Main Empirical Results on the Impact of Japanese Intervention on Daily Yen-Dollar Exchange Rate Volatility (16 Studies) ${ }^{1}$

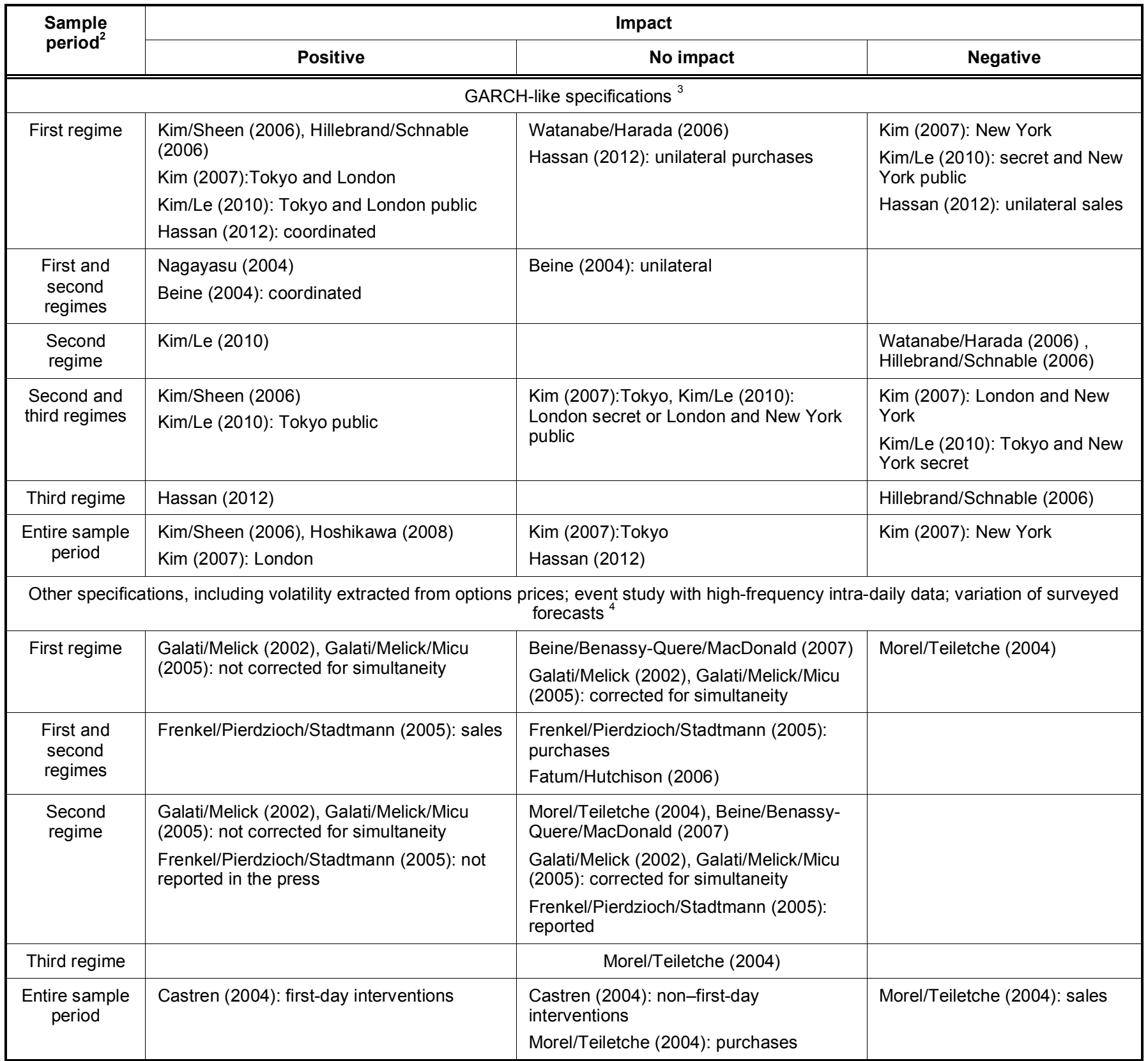

Notes: ${ }^{1}$ Galati, Melick, and Micu (2005) subsumed Galati and Melick (2002) for 1991-6; ${ }^{2}$ The sample period of a study may not exactly correspond to the threeregime breakdown; ${ }^{3}$ Studies used the absolute value of contemporaneous intervention as the key explanatory variable, jointly estimated with a conditional mean equation; ${ }^{4}$ Castren (2004), Galati/Melick (2002), Galati/Melick/Micu (2005), Frenkel/Pierdzioch/Stadtmann (2005), and Morel/Teiletche (2004) used volatility extracted from options prices; Fatum/Hutchison (2006) used an event study with high-frequency intra-daily data; and Beine/Benassy-Quere/MacDonald (2007) used variation of surveyed forecasts.

under the first regime and that it had negative impact on short-term variance but only for Japanese (not coordinated US) interventions. Likewise, evidence of positive impact disappeared when a Markov regimeswitching model was used to consider two states of volatility: high and low. Beine et al. (2003) showed that interventions had little impact on the conditional variance of weekly exchange rate returns for $1991-5 .^{11}$

Kim (2007) argued that any evidence of positive impact reflected the positive feedback between

\footnotetext{
${ }^{11}$ For coordinated interventions, the impact was positive in a low volatility
} environment, while it was negative in a high volatility environment. 
volatility and intervention, which was not controlled for by most GARCH-type studies. In fact, when daily exchange rate data were used, intervention raised volatility both under the first regime and under the combined second/third regime. When intra-daily data (consisting of Tokyo, London and New York trading) were used, however, the positive impact of intervention on the conditional variance of exchange rate returns diminished as trading moved from Tokyo to New York. Under the former regime, the impact remained positive during Tokyo and London trading, while it was negative during New York trading. Under the latter regime, the impact of intervention was not significant during Tokyo trading, but it became significantly negative during London and New York trading.

As a measure of volatility, five studies used the second moment of the risk-neutral density (RND) of expectations drawn from option prices, which may perhaps be better characterized as a measure of uncertainty, rather than of volatility. First, Castren (2004) used over-the-counter (OTC) options data to find that first-time interventions conducted after at least five days of no intervention significantly raised market volatility for April 1992 - December 2003. Second, Galati et al. (2005), subsuming Galati and Melick (2002) for 1991-6, used exchange-traded options data and Reuter reports to show that the predicted value of intervention estimated from an intervention reaction function had no statistically significant impact on volatility for September 1993 - April 2000, whether intervention was public or secret. The impact became significantly positive, however, when the actual, rather than the predicted, value of intervention was used, leading the authors to conclude that any evidence of positive impact in other studies was an artifact of simultaneity.

Third, Frenkel, Pierdzioch, and Stadtmann (2005) likewise used the implied volatility of yen-dollar foreign currency options for 1993-2000 to find that the coefficient for intervention was positive but ceased to become statistically significant when an intervention dummy was added, suggesting that it was the presence of official trading, not trading volume, that caused the volatility to rise. Moreover, when different types of intervention were considered, it was only the secret or yen-selling interventions that raised the volatility. But this last result contradicts the findings of the GARCH literature (e.g., Kim and Le 2010), which seems to suggest that publicity generates volatility. Finally, Morel and Teiletche (2005) used an event study methodology to find that the impact of intervention was negative for April 1992 - October 2003 (though it was not statistically significant for later subperiods when the sample was divided into three).

The event study of Fatum and Hutchison (2006) is the only empirical work on Japan that employed a directly observable measure of market volatility, namely, the daily variance of the yen-dollar exchange rate calculated from 10 minutes-frequency returns over 48 hours preceding and succeeding each event. The authors found no systematic link between intervention and volatility for April 1991 - December 2000. In a slightly different context, Beine, Benassy-Quere, and MacDonald (2007) used the coefficient of variation of monthly short-term exchange rate forecasts collected by Consensus Economics (London) as a measure of volatility to find that, for January 1992 - December 1994 and January 1996 - March 2001, monthly intervention (given by the number of intervention days in a month) generally increased volatility though the impact was not statistically significant. In view of the fact that the realized value of sample variance directly corresponds to the volatility likely perceived by market participants, perhaps greater weight might be given to the findings of these studies. Though there were specific instances where intervention affected volatility (e.g., Cai et al. 2001), ${ }^{12}$ the overall impact appears to have been ambiguous.

\section{CHANNELS OF INTERVENTION EFFECTIVE- NESS}

Our review of post-2001 studies that used official Japanese data suggests that intervention was effective on average in influencing daily yen-dollar exchange rate returns over 1991-2004 when it was coordinated or when it was large and infrequent; effectiveness was somewhat greater when it was known to the public. The magnitude of impact, however, was numerically small: even the most favorable point estimate was a mere 0.7 percent for an intervention of $¥ 1$ trillion (Ito 2007 ) or at most 0.14 percent (about $¥ 0.11-17$ ) for an average-sized intervention during $1991-2004 .^{13}$ Almost all studies suffer from the simultaneity bias, but the feedback between intervention and the exchange rate works against accepting the hypothesis of effectiveness, thus justifying or strengthening our

\footnotetext{
${ }^{12}$ Cai et al. (2001) used high-frequency intra-daily exchange rate returns to show that two significant episodes of intervention in 1998 contributed to a significant increase in volatility.

${ }^{13}$ When a dummy variable (rather than the actual amount) was used for intervention, the point estimate in one instance was about 0.5 percent for "large" interventions (Hassan 2012).
} 
overall positive assessment. The empirical results were more ambiguous with respect to the impact of intervention on volatility. While GARCH-like studies tended to support a positive impact on volatility, a rise in the jointly estimated conditional variance of daily returns has no readily identifiable counterpart in real life. Studies that utilized alternative measures of market volatility were mixed but tended to find little impact.

Any effectiveness of intervention appeared shortlived, lasting not much longer than a day (Nagayasu 2004; Beine 2004). Studies based on intra-daily exchange rate returns showed that the impact lasted at least several hours (Kim 2007; Kim and Le 2010); Dominguez (2003b) showed that the impact of intervention in Tokyo did not last longer than eight hours. The martingale property of daily exchange rate returns implies that any impact should be permanent, but evidence suggests otherwise. Beine et al. (2003) found no evidence of impact on either the level or the volatility of the exchange rate in weekly data. Impact typically found in an event study tended to weaken or even disappear when the pre/post-event window was lengthened (Morel and Teiletche 2004; Fatum and Hutchison 2006; Fratzscher 2008). A study showed that about 40 percent of the impact of intervention was reversed the next day (Castren 2004), which was corroborated by Evans and Lyons (2005) in the context of the response of daily exchange rate returns to the arrival of macroeconomic news. ${ }^{14}$ The transitory nature of intervention impact is consistent with the larger literature on intervention (e.g., Edison 1993; Dominguez 2006).

Although the literature has conventionally identified portfolio balance adjustment and signaling as the two main channels through which intervention affects exchange rates, it is difficult to believe that any of these is important in Japan, at least when effectiveness is measured in daily frequency. For one thing, any intervention-induced portfolio adjustment is miniscule in relation to the stocks of Japanese and US government debt even if the substitutability between the two can be shown to be sufficiently imperfect. For example, the net cumulative amount of interventions was less than 15 percent of the total stock of Japanese government bonds (JGBs) in 2004. The largest daily or even monthly portfolio adjustment during 1991-2004 was a

\footnotetext{
${ }^{14}$ Evans and Lyons (2005) showed that part of the initial impact of macroeconomic news on the daily euro-dollar rate was systematically reversed over several days during April 1993 - June 1999, likely reflecting persistent effects on trading behavior.
}

small fraction of this. This is not to deny the portfolio balance effect over the medium term when there is a large, sustained intervention in which domestic and foreign assets are exchanged, as was the case during the period of the great intervention. ${ }^{15}$ But such would be a rare event indeed.

Second, the signaling effect, as the term is normally used in the literature, refers to an intervention-induced change in market expectations about the future stance of monetary policy. For this to be operational there must be (i) a link between intervention and actual future monetary policy and (ii) a link between intervention and market expectations of future monetary policy. Unless the first of the two links is consistent, an observation of intervention would not convey meaningful information about monetary policy and hence should not affect expectations. Humpage (2003) argues that central banks are not likely to use intervention as a signaling device for monetary policy because if they validate the signals, the intervention is no longer sterilized. In countries like Japan and the United States, moreover, the central bank could even lose its independence if it altered monetary policy systematically in response to interventions by fiscal authorities. ${ }^{16}$

An important part of the signaling effect operates when an entity conducting intervention makes a credible commitment to a change in future monetary policy, suggesting that its effectiveness hinges upon whether the central bank is independent of government oversight. In Japan, this may have been possible before 1 April 1998, when the new Bank of Japan Law came into force giving operational independence to the central bank. Watanabe (1994) showed that a fall (rise) in the discount rate during 1973-92, and an increase (decrease) in the growth rate of money during 197692 , were consistently preceded by purchases (sales) of foreign exchange. Takagi and Okada (2013), estimating a probit model of the directional consistency between intervention and future monetary policy (the dependent variable $=1$ if consistent; 0 otherwise), found that the coefficient of central bank independence was significant and negative if a dummy variable was included for the period of quantitative easing (when the direction of intervention coincided with that of monetary

\footnotetext{
${ }^{15}$ The increase in foreign exchange reserves from 2000 to 2004 amounted to 44 percent of the corresponding increase in Japan's total external portfolio assets.

${ }^{16}$ Studies of the signaling effect of US intervention are mixed. While Lewis (1995) identified Granger causality from intervention to future monetary policy, Kaminsky and Lewis (1996) and Klein and Rosengren (1991) reported conflicting or negative findings (see also Fatum and Hutchison 1999).
} 
easing). The authors thus concluded that the signaling effect of intervention diminished after April 1998.

Fiscal authorities may use intervention to signal something other than monetary policy (Truman 2003). More broadly, then, the signaling effect of intervention can be understood as a channel through which any information is communicated to market participants. If so, given the convention of $t+2$ settlements, it is almost a truism that signaling operates in Japan and can even be the dominant channel. There is a plenty of evidence to support this claim. For example, when a dummy variable was included for intervention, the impact of size on volatility disappeared (Frenkel et al. 2005); firstday interventions were more effective, when they were separated from subsequent interventions on successive days (Castren 2004; Ito 2005). The signaling effect does not mean that any announcement would do the trick. Fatum (2009) found that a dummy variable for false reporting did not affect the exchange rate during 1999-2003, nor did the dummy variables for official intervention announcements. It is possible that, given the scale of intervention during this period, false reports or official announcements did not contain much new information beyond what the market participants had already been expecting.

The temporary nature of any impact, combined with the findings that secret interventions could in some cases be effective, lends support to the validity of the market microstructure channel (Evans and Lyons 2002, 2005). In this view, intervention if perceived by the market acts like any other information about fundamentals (Ehrmann and Fratzscher 2005); regardless of whether or not it is perceived, intervention always affects order flows (i.e., the net of buyerinitiated and seller-initiated orders), ${ }^{17}$ which may trigger portfolio rebalancing or convey information. The findings that public or coordinated interventions sometimes increased market volatility are consistent with the microstructure view of intervention working through the aggregation of new information by the market (Beine et al. 2009). ${ }^{18}$ If intervention conveys no new information, after the traders have adjusted their positions and quotes in response to a new pattern of

\footnotetext{
${ }^{17}$ Evans and Lyons (2002), discussing the critical role of order flow, showed that it explained over 40 percent of daily changes in the yen-dollar exchange rate between May and August 1996.

${ }^{18}$ Obtaining daily volatility from the realized hourly returns for the day, Beine et al. (2009) found that during 1989-2001, only coordinated intervention increased the volatility of the daily deutsche mark-dollar (or euro-dollar after 1999) exchange rate. Their volatility equation included a dummy variable for Japanese intervention, for which official Japanese intervention data were employed (press reports were used for January 1989 - March 1991).
}

order flow, the exchange rate would return to the original level (Beine, Laurent and Palm 2009). Cai et al. (2001) showed that order flow was the most important explanatory variable for the unprecedented volatility of the yen-dollar exchange rate observed in 1998 (see Figure 2).

It is possible that an initial move in the exchange rate sets in motion the herd-like behavior of traders who follow a chartist strategy. In a market inhabited by chartists, intervention might succeed in breaking up the exchange rate's self-propelling drift. Documenting the chartist behavior of traders in the yen-dollar, pounddollar, and euro-dollar markets from August 1999 to April 2000, Osler (2003) showed that take-profit orders were clustered at round numbers, while stop-loss orders were clustered just below or above those numbers depending on whether they were sales or purchases. Once the exchange rate crosses the "support and resistance levels," herd behavior typically sets in to accelerate the movement of the exchange rate towards one direction. In such an environment, intervention could conceivably be effective in preventing the exchange rate from trending further downward or upward by creating two-way trades at or around the support and resistance levels. Intervention could even reverse order flow dynamics and trigger a herd behavior in the opposite direction.

The diversity of results reported in the literature suggests that the impact of intervention depends, not only on such characteristics as size and frequency, but also on the conditions under which it takes place. Fratzscher (2008) showed, for the euro-dollar and yen-dollar markets, that intervention tended to be more effective during periods of high volatility and uncertainty. Beine et al. (2003) used a Markov regimeswitching model (capturing high and low volatility) to show that, during 1991-5, coordinated intervention was destabilizing in a low volatility state but stabilizing in a high volatility state (see Beine et al. 2009 for a similar result on the deutsche mark-dollar market). This may to some extent reflect what Sarno and Taylor (2001) called the coordination channel of intervention. When uncertainty is high, intervention could stabilize the market by anchoring exchange rate expectations towards a level consistent with fundamentals (see also Morel and Teiletche 2005).

All these considerations mean that some interventions can be effective but others are not. Dominguez (2003b) identified for the yen-dollar market during 1991-2002 that 47 percent of the daily returns 
on 218 days had a correct sign. That is, intervention was effective at most about half the time. Because each intervention episode is unique, econometric tests of the average impact of intervention can only yield mixed results, while event studies could find more instances of effectiveness. Galati and Melick (2002), using the same data set, found effectiveness during 1991-6 with an event study but their econometric analysis failed to find any impact on yen-dollar exchange rate returns or volatility. Masaaki Shirakawa (2008), Governor of the Bank of Japan during 2008-13, stated that the only meaningful assessment of intervention was that of intervention in a specific, exceptional circumstance. While expressing general skepticism about the effectiveness of intervention, he further argued that monetary authorities should intervene only when in their view the probability of success was high (p. 290).

\section{CONCLUSION}

This paper has reviewed post-2001 studies on Japanese intervention that used the newly released official data. Because these studies all used the same data set covering roughly the same period (all or part of April 1991 - March 2004), much of the differences in empirical results could be attributed to the choice of subsample (and the associated conditions) and methodology, making it possible to draw broad generalizations about the impact of intervention. Studies were on average supportive of the effectiveness of intervention in influencing the level of the yen-dollar exchange rate in a desired direction, especially when it was coordinated, large and infrequent, or public, although the magnitude of any impact was numerically very small. Studies were less conclusive about the impact of intervention on volatility. If anything, intervention was shown more likely to increase volatility when it was public.

Any impact of intervention appeared short-lived, lasting not much longer than a day. A reversal of the initial impact appeared to occur on subsequent days, so that no impact was detected in weekly data and any impact found in an event study tended to dissipate as the pre/post-event window was lengthened. Under Japan's institutional setup, where fiscal authorities are in charge of intervention decisions, it is difficult to believe that intervention is used as the signal for a future change in monetary policy (especially after April 1998 when the central bank was granted independence). The signaling channel, as the term is generally understood, does not exist in Japan, except when the two entities explicitly collaborate in pursuit of common objectives. Likewise, the portfolio balance channel cannot explain any impact of daily intervention, given the miniscule size of intervention-induced portfolio adjustment relative to the stocks of domestic and foreign assets. This is not to deny that large cumulative interventions could influence the exchange rate over the medium term, as might have happened subsequent to the great intervention of 2003-4 (Iwata and Takenaka 2012).

These considerations lend support to market microstructure as the primary channel through which intervention affected the exchange rate. If perceived by the market, intervention acts like any other information; regardless of whether or not it is perceived, intervention always affects orders flows, in turn triggering portfolio rebalancing or conveying information, which the market must absorb. If no new information is involved, the exchange rate eventually returns to the original level. Where technical analysis prevails, intervention could reverse order flow dynamics and correct an evolving misalignment of the exchange rate. In what Sarno and Taylor (2001) called the coordination channel, intervention could stabilize the market during a period of heightened uncertainty, by providing an anchor to exchange rate expectations. The overriding message of the empirical literature is that the impact of intervention depends on the conditions under which it takes place. Thus, some interventions were effective but others were not; some increased volatility but others had the opposite or no impact. This explains why econometric tests of the average impact of intervention yielded mixed results.

It is now time to recognize that each intervention is a unique event. Much effort has been expended in the past decade to attempt to estimate the average impact of intervention on exchange rates, but a further effort along the same lines does not seem to be productive. We know that some interventions work while others do not. It might be better to devote more resources to investigating why specific intervention episodes worked but others did not. From the point of view of policymakers, the advice of Governor Shirakawa (2008) is well taken: they should intervene only when they are convinced that the probability of success is high. But how can they evaluate the probability of success when they have little understanding of what explains success? Given that intervention works sometimes, but we do not know why it does, another distinguished former central banker compared intervention to a drug that has not received, and is not 
likely to receive, government approval for general use (Truman 2003). We should also heed his advice: be modest in any claims about the effectiveness of foreign exchange market intervention.

\section{ACKNOWLEDGEMENT}

The author thanks Hali Edison, Taro Esaka, Val Lambson, Ted Truman, and Yushi Yoshida for their comments and encouragement. He remains responsible for any remaining errors.

\section{REFERENCES}

Beine, Michel. 2004. "Conditional Covariances and Direct Central Bank Interventions in the Foreign Exchange Markets." Journal of Banking and Finance 28: 1385-411. http://dx.doi.org/10.1016/S0378-4266(03)00124-9

Beine, Michel, Sebastien Laurent, and Christelle Lecourt. 2003. "Official Central Bank Interventions and Exchange Rate Volatility: Evidence from a Regime-Switching Analysis." European Economic Review 47: 891-911. http://dx.doi.org/10.1016/S0014-2921(02)00306-9

Beine, Michel and Oscar Bernal. 2007. "Why Do Central Banks Intervene Secretly? Preliminary Evidence from the BOJ." Journal of International Financial Markets, Institutions, and Money 17: 291-306. http://dx.doi.org/10.1016/j.intfin.2005.12.003

Beine, Michel and Christelle Lecourt. 2004. "Reported and Secret Interventions in the Foreign Exchange Markets." Finance Research Letters 1: 215-25. http://dx.doi.org/10.1016/j.frl.2004.08.002

Beine, Michel, Sebastien Laurent, and Franz C. Palm. 2009. "Central Bank FOREX Interventions Assessed Using Realized Moments." Journal of International Financial Markets, Institutions, and Money 19: 112-27. http://dx.doi.org/10.1016/j.intfin.2007.09.001

Beine, Michel, Agnes Benassy-Quere, and Ronald MacDonald. 2007. "The Impact of Central Bank Intervention on Exchange-Rate Forecast Heterogeneity." Journal of the Japanese and International Economies 21: 38-63. http://dx.doi.org/10.1016/j.jiie.2005.06.001

Cai, Jun, Yan-Leung Cheung, Raymond S. K. Lee, and Michael Melvin. 2001. "'Once-in-a-Generation' Yen Volatility in 1998: Fundamentals, Intervention, and Order Flow." Journal of International Money and Finance 20: 327-47. http://dx.doi.org/10.1016/S0261-5606(00)00056-5

Castren, Olli. 2004. "Do Options-Implied RND Functions on G3 Currencies Move Around the Times of Interventions on the JPY/USD Exchange Rate?" Working Paper No. 410. Frankfurt: European Central Bank.

Chang, Yuanchen and Stephen J. Taylor. 1998. "Intraday Effects of Foreign Exchange Intervention by the Bank of Japan." Journal of International Money and Finance 17: 191-210. http://dx.doi.org/10.1016/S0261-5606(97)00056-9

Chang, Yuanchen. 2006. "The Accuracy of Reports of Foreign Exchange Intervention by the Bank of Japan: Does Tokyo Know More?" Journal of International Money and Finance 25: 1241-56. http://dx.doi.org/10.1016/j.jimonfin.2006.09.007

Chaboud, Alain P. and Owen F. Humpage. 2005. "An Assessment of the Impact of Japanese Foreign Exchange Intervention: 1991-2004." International Finance Discussion Paper No. 824. Washington: Board of Governors of the Federal Reserve System.
Dominguez, Kathryn M. E. 1998. "Central Bank Intervention and Exchange Rate Volatility." Journal of International Money and Finance 17: 161-90. http://dx.doi.org/10.1016/S0261-5606(97)98055-4

Dominguez, Kathryn M. E. 2003a. "The Market Microstructure of Central Bank Intervention." Journal of International Economics 59: 25-45. http://dx.doi.org/10.1016/S0022-1996(02)00091-0

Dominguez, Kathryn M. E. 2003b. "Foreign Exchange Intervention: Did It Work in the 1990s?" Pp. 217-45 in Dollar Overvaluation and the World Economy, edited by $\mathrm{C}$. Fred Bergsten and John Williamson. Washington: Institute for International Economics.

Dominguez, Kathryn M. E. 2006. "When Do Central Bank Interventions Influence Intra-daily and Longer-term Exchange Rate Movements?" Journal of International Money and Finance 25: 1051-71. http://dx.doi.org/10.1016/j.jimonfin.2006.08.009

Dominguez, Kathryn M. E. and Freyan Panthaki. 2003. "The Influence of Actual and Unrequited Interventions." International Journal of Finance and Economics 12: 171-200. http://dx.doi.org/10.1002/ijfe.326

Edison, Hali J. 1993. "The Effectiveness of Central-Bank Intervention: A Survey of the Literature after 1982." Special Papers in International Economics No. 18. Princeton, NJ: International Finance Section, Department of Economcis, Princeton University.

Ehrmann, Michael and Marcel Fratzscher. 2005. "Exchange Rates and Fundamentals: New Evidence from Real-Time Data." Journal of International Money and Finance 24: 317-41. http://dx.doi.org/10.1016/j.jimonfin.2004.12.010

Evans, Martin D. D. and Richard K. Lyons. 2002. "Order Flow and Exchange Rate Dynamics." Journal of Political Economy 110: $170-80$. http://dx.doi.org/10.1086/324391

Evans, Martin D. D. and Richard K. Lyons. 2005. "Do Currency Markets Absorb News Quickly?" Journal of International Money and Finance 24: 197-217.

http://dx.doi.org/10.1016/j.jimonfin.2004.12.004

Fatum, Rasmus. 2009. "Official Japanese Intervention in the JPY/USD Exchange Market: Is It Effective and Through Which Channel Does It Work?" Bank of Japan Monetary and Economic Studies 27: 75-98.

Fatum, Rasmus and Michael Hutchison. 1999. "Is Intervention a Signal of Future Monetary Policy? Evidence from the Federal Funds Futures Market." Journal of Money, Credit, and Banking 31: 54-69. http://dx.doi.org/10.2307/2601139

Fatum, Rasmus and Michael Hutchison. 2005. "Foreign Exchange Intervention and Monetary Policy in Japan, 2003-04." International Economics and Economic Policy 2: 241-60. http://dx.doi.org/10.1007/s10368-005-0036-y

Fatum, Rasmus and Michael Hutchison. 2006. "Effectiveness of Official Daily Foreign Exchange Market Intervention Operations in Japan." Journal of International Money and Finance 25: 199-219. http://dx.doi.org/10.1016/j.jimonfin.2005.11.007

Fatum, Rasmus and Michael M. Hutchison. 2010. "Evaluating Foreign Exchange Market Intervention: Self-Selection, Counterfactuals and Average Treatment Effects." Journal of International Money and Finance 29: 570-84. http://dx.doi.org/10.1016/j.jimonfin.2009.12.009

Fratzscher, Marcel. 2005. "Strategies of Exchange Rate Policy in G3 Economies." Economics Letters 89: 68-74. http://dx.doi.org/10.1016/j.econlet.2005.05.014

Fratzscher, Marcel. 2008. "Oral Interventions versus Actual Interventions in FX Markets: An Event-Study Approach." Economic Journal 118: 1079-106. http://dx.doi.org/10.1111/j.1468-0297.2008.02161.x 
Frenkel, Michael, Christian Pierdzioch, and Georg Stadtmann. 2004. "The Accuracy of Press Reports Regarding the Foreign Exchange Interventions of the Bank of Japan." Journal of International Financial Markets, Institutions, and Money 14: 25-36.

http://dx.doi.org/10.1016/S1042-4431(03)00042-8

Frenkel, Michael, Christian Pierdzioch, and Georg Stadtmann. 2005. "The Effects of Japanese Foreign Exchange Market Interventions on the Yen/US Dollar Exchange Rate Volatility." International Review of Economics and Finance 14: 27-39. http://dx.doi.org/10.1016/j.iref.2003.09.003

Galati, Gabriele and William Melick. 2002. "Central Bank Intervention and Market Expectations." BIS Papers No. 10. Basel: Bank for International Settlement.

Galati, Gabriele, William Melick, and Marian Micu. 2005. "Foreign Exchange Market Intervention and Expectations: The Yen/Dollar Exchange Rate." Journal of International Money and Finance 24: 982-1011. http://dx.doi.org/10.1016/j.jimonfin.2005.07.004

Hassan, Marwa. 2012. "Japanese Foreign Exchange Intervention: A Tale of Pattern, Size, or Frequency." Japan and the World Economy 24: 184-92. http://dx.doi.org/10.1016/j.japwor.2012.03.002

Hillebrand, Eric and Gunther Schnable. 2006. "A Structural Break in the Effects of Japanese Foreign Exchange Intervention on Yen/Dollar Exchange Rate Volatility." Working Paper No. 650. Frankfurt: European Central Bank.

Hoshikawa, Takeshi. 2008. "The Effect of Intervention Frequency on the Foreign Exchange Market: The Japanese Experience." Journal of International Money and Finance 27: 547-59. http://dx.doi.org/10.1016/j.jimonfin.2008.01.004

Humpage, Owen F. 2003. "Government Intervention in the Foreign Exchange Market." Working Paper 03/15. Cleveland, $\mathrm{OH}$ : Federal Reserve Bank of Cleveland.

Ito, Takatoshi. 2003. "Is Foreign Exchange Intervention Effective? The Japanese Experience in the 1990s." Pp. 126-53 in Monetary History, Exchange Rates and Financial Markets, Vol. 2, edited by Paul Mizen. Cheltenham, U.K.: Edward Elgar.

Ito, Takatoshi. 2005. "Interventions and Japanese Economic Recovery." International Economics and Economic Policy 2: 219-39. http://dx.doi.org/10.1007/s10368-005-0034-0

Ito, Takatoshi. 2007. "Myths and Reality of Foreign Exchange Interventions: An Application to Japan." International Journal of Finance and Economics 12: 133-54. http://dx.doi.org/10.1002/ijfe.336

Iwata, Kazumasa and Shinji Takenaka. 2012. "Central Bank Balance Sheet Expansion: Japan's Experience." Pp. 132-59 in "Are Central Bank Balance Sheets in Asia Too Large?" BIS Papers No. 66. Basel: Bank for International Settlements.

Kaminsky, Graciela L. and Karen K. Lewis. 1996. "Does Foreign Exchange Intervention Signal Future Monetary Policy." Journal of Monetary Economics 37: 285-312. http://dx.doi.org/10.1016/S0304-3932(96)90038-0

Kearns, Jonathan and Roberto Rigobon. 2005. "Identifying the Efficacy of Central Bank Interventions: Evidence from Australia and Japan." Journal of International Economics 66: 31-48.

http://dx.doi.org/10.1016/j.jinteco.2004.05.001

Kim, Suk-Joong. 2007. "Intraday Evidence of Efficacy of 1991-2004 Yen Intervention by the Bank of Japan." Journal of International Financial Markets, Institutions, and Money 17: $341-60$.

http://dx.doi.org/10.1016/j.intfin.2006.01.001

Kim, Suk-Joong and Jeffrey Sheen. 2006. "Interventions in the YenDollar Spot Market: A Story of Price, Volatility and Volume." Journal of Banking and Finance 30: 3191-214. http://dx.doi.org/10.1016/j.jbankfin.2005.12.005
Kim, Suk-Joong and Anh Tu Le. 2010. "Secrecy of Bank of Japan's Yen Intervention: Evidence of Efficacy from Intra-daily Data." Journal of the Japanese and International Economies 24: 369-94.

http://dx.doi.org/10.1016/j.jjie.2010.02.002

Klein, Michael and Eric S. Rosengren. 1991. "Foreign Exchange Intervention as a Signal of Monetary Policy." New England Economic Review (May/June): 39-50.

Lewis, Karen K. 1995. "Are Foreign Exchange Intervention and Monetary Policy Related and Does It Really Matter?" Journal of Business 68: 185-214. http://dx.doi.org/10.1086/296660

Mizoguchi, Zenbei. 2004. "Kawase Zuikan," Tokyo: Japan Center for International Finance (available at: www.jcif.or.jp/docs/ 20040917.pdf).

Morel, Christophe and Jerome Teiletche. 2005. "Do Interventions in Foreign Exchange Markets Modify Investors' Expectations? The Experience of Japan between 1991 and 2003." Working Paper 2005-04. Paris: University of Paris Dauphine.

Nagayasu, Jun. 2004. "The Effectiveness of Japanese Foreign Exchange Interventions during 1991-2001." Economics Letters 84: 377-81. http://dx.doi.org/10.1016/j.econlet.2004.03.007

Neely, Christopher J. 2005. "An Analysis of Recent Studies of the Effect of Foreign Exchange Intervention." Federal Reserve Bank of St. Louis Review 87: 685-717.

Osler, Carol L. 2003. "Currency Orders and Exchange Rate Dynamics: An Explanation for the Predictive Success of Technical Analysis." Journal of Finance 58: 1791-819. http://dx.doi.org/10.1111/1540-6261.00588

Park, Haesik and Chi-Young Song. 2008. "Japanese Vocal Intervention and the Yen/Dollar Exchange Rate." Japan and the World Economy 20: 61-81. http://dx.doi.org/10.1016/j.japwor.2006.09.001

Sakakibara, Eisuke. 2000. Nihon to Sekai ga Furueta Hi. Tokyo: Chuo Koron Shinsha.

Sakata, Shun and Fumiko Takeda. 2013. "Effects of Oral Intervention on Fluctuations in Exchange Rates: Evidence from Japan 1996-2011." Journal of Reviews on Global Economics 2: 60 78

Sarno, Lucio and Mark P. Taylor. 2001. "Official Intervention in the Foreign Exchange Market: Is It Effective and, If So, How Does It Work?" Journal of Economic Literature 39: 839-68. http://dx.doi.org/10.1257/jel.39.3.839

Shirakawa, Masaaki. 2008. Gendai no Kinyu Seisaku. Tokyo: Nihon Keizai Shinbun Shuppansha.

Takagi, Shinji and Hiroki Okada. 2013. "Central Bank Independence and the Signaling Effect of Intervention: A Preliminary Exploration." Discussion Papers in Economics and Business No. 13-04. Osaka: Graduate School of Economics, Osaka University.

Taylor, John B. 2006. "Lessons from the Recovery from the 'Lost Decade' in Japan: The Case of the Great Intervention and Monetary Injection." Paper presented at a conference held at the Cabinet Office, Government of Japan, September 14, Tokyo.

Taylor, John B. 2007. Global Financial Warriors: The Untold Story of International Finance in the Post 9/11 World. New York: W.W. Norton.

Truman, Edwin M. 2003. "Foreign Exchange Intervention: Did It Work in the 1990s?" Pp. 247-65 in Dollar Overvaluation and the World Economy, edited by C. Fred Bergsten and John Williamson. Washington: Institute for International Economics.

Vitale, Paolo. 2007. "An Assessment of Some Open Issues in the Analysis of Foreign Exchange Intervention." International Journal of Finance and Economics 12: 155-70.

http://dx.doi.org/10.1002/ijfe.327 
Watanabe, Toshiaki and Kimie Harada. 2006. "Effects of the Bank of Japan's Intervention on Yen/Dollar Exchange Rate Volatility." Journal of the Japanese and International Economies 20: 99111.

http://dx.doi.org/10.1016/j.jjie.2004.08.001
Watanabe, Tsutomu. 1994. "The Signaling Effect of Foreign Exchange Intervention: The Case of Japan." Pp. 258-86 in Exchange Rate Policy and Interdependence: Perspectives from the Pacific Basin, edited by Reuven Glick and Michae M. Hutchison. Cambridge and New York: Cambridge University Press.

DOI: http://dx.doi.org/10.6000/1929-7092.2014.03.07

(C) 2014 Shinji Takagi; Licensee Lifescience Global.

This is an open access article licensed under the terms of the Creative Commons Attribution Non-Commercial License (http://creativecommons.org/licenses/by-nc/3.0/) which permits unrestricted, non-commercial use, distribution and reproduction in any medium, provided the work is properly cited. 